THURSDAY, NOVEMBER $\mathbf{1 4}, \mathbf{1 8 7 2}$

\section{EXPLORATION OF THE SOUTH POLAR REGIONS}

$\mathrm{N}$ the various explorations which the last few years 1 have seen, it must be admitted that the South Pole has been neglected, and its rival, the North Pole, has had it all its own way. It is not to be wondered at, therefore, that Dr. Neumayer, with whom the Exploration of the South Polar regions has been a cherished project from his youth, and who for many years has lived in the hope of some day having the privilege granted him of taking part in an expedition on board a German ship that might have the honour of penetrating the South-Polar circle, and clearing up the mystery that lies beyond, will allow this state of things to continue without protest. Since this hope has been time after time frustrated, and because he fears that now it may never be realised, he is determined to do what he can to rouse an active interest in the subject among scientific men. By lectures in various parts of Germany, and otherwise, he endeavoured some little time ago to set afoot an exploring party, whose observations might have been of great use in connection with the now not very distant Transit of Venus, but in this, too, he failed; so that now there remains only the hope that, in connection with the scientific expeditions to the south for the observation of that momentous astronomical event, something may be done towards the realisation of the "darling scheme of his youth." Hence, to awaken a general interest in antarctic explorations, as well as to show what remains to be done, Dr. Neumayer has reprinted, in the form of a pamphlet, a long article of his from the "Zeitschrift der Gesellschaft für Erdkünde," on the subject, referring to his numerous lectures and writings on the subject, and has given a brief sketch of the progress of discovery in the South Polar regions, and an admirable summary of the points to which any expedition should direct its attention--to which, anxious to second his efforts, we gladly draw attention.

Of maritime expeditions, those to the Polar regions have had a lasting interest for geographers, both as leading to the solution of important scientific problems, and as being of value from a more material point of view. The importance of scientific observation inside the Polar circle is evident, Dr. Neumayer declares, to all who have any knowledge of the phenomena on the surface of the globe. Without such observations there exists a void and a lamentable one-sidedness in our knowledge, offering a fertile field for numberless, and mostly worthless, hypotheses. What have been the results of efficient observation in the far north for the confirmation and correction of our knowledge in the departments of magnetism, climatology, the geographical distribution of plants and animals, the laws of ocean currents, is shown by a superficial glance at the history of the development of these departments of science. But Dr. Neumayer maintains that for the purpose of discovering those general laws which are necessary as guides and standards in the interpretation of phenomena in climatology and physical geography generally, the South Polar regions are much better adapted than those of the North. A glance at the globe, he maintains, shows that such results can be No. $\times 59-$ - Vol, vX. obtained only by the expenditure of vast means and laborious research in the north, on account of the nature of the division of the land and water, which also throws difficulties in the way of a satisfactory study of the phenomena; whereas no such difficulties and disturbances are presented by the prevailing sea of the South Polar regions. These statements could be proved by many examples from physical geography, but it is only necessary to refer to the valuable additions which have been made by researches in high south latitudes to our knowledge of the laws of the relation between the distribution of the pressure of the air and of heat, and of the laws of winds. Moreover, Dr. Neumayer maintains that very valuable light would be thrown on the laws of the distribution of living organisms by explorations in this quarter, where there is scarcely any land but a few scattered islands.

Dr. Neumayer then proceeds to give a sketch of the history of discovery in the South Polar regions, dividing it into three periods. The first of these periods begins with the sixteenth century, and ends with the determination of the south point of America by Schoelten and Lemaine in 1616 . The second period extends to the beginning of the present century, and the third from that time onwards.

The voyages embraced in the first period were not Polar voyages in the strict sense, for no one stepped over the Polar circle, and their main object was to fix the route to India and the Spanish colonies on the west coast of South America. The expeditions which went south during the second period had for their purpose to discover and fix the limits of the great southern continent which theoretical geographers supposed must exist in those regions in order that the balance of land might be maintained. The expeditions which have gone out to this quarter during the present century have had for their purpose mainly the observation of phenomena for scientific purposes.

Of the great voyagers belonging to the first period, it can hardly be said that any made discoveries in what is generally considered the Antarctic region. Sebald de West, in January 1600 , saw a group of islands in $50^{\circ} 40^{\prime}$ S. and $59^{\circ} \mathrm{W}$., which were called Sebald's Islands, and which were possibly the same as the Falkland Islands, whose proper discovery falls to a later time. One of the minor voyagers of this period, Dick Gerritz, discovered an island group in $6 \mathrm{I}^{\circ} \mathrm{S}$. lat. and seems to have reached $64^{\circ}$. This ice-bound group was probably the same as that now called South Shetland, although it is possible Gerritz had seen Palmer's Land. During this period discoveries only reached the higher latitudes south of Cape Horn; in other circumpolar parts the 4oth parallel had only been reached at the Cape of Good Hope; and in the Indian Ocean, on the way to Batavia, the islands of St. Paul and New Amsterdam were already known in the beginning of the 17 th century.

The earliest of the discoveries of the second period were those of the famous Abel Tasman. The maps of Mercator in 1628 attach the north coast of New Holland to the great continent of Australasia, that spreads itself all over the South Polar region, and annexes the discoveries of Dick Gerritz to South America. The unrestrained fancy of the geographers of the time even leads them to 
set down a continuation of the Cordilleras as running through the "great south continent." This delusion Tasman destroyed, when, in the year 1642 , he sailed round the south of New Holland, and discovered Van Diemen's Land; he also discovered the west coast of New Zealand. La Roche, in 1675 , discovered South Georgia; while the Malouins (I700-I712) place the Falkland Islands accurately on the maps. The voyages of Hay and Lozier Bonnet circumscrioed considerably the extent of the south continent in the Atlantic and Indian Oceans; but through the discovery of Cape Circumcision in about $52^{\circ} \mathrm{S}$. lat. and $10^{\circ} \mathrm{E}$. long., it was believed a new proof of its existence had been gained.

Dr. Neumayer pays a very high tribute to Cook for the restless energy with which he pursued his work, and the vast and valuable additions he made to the then scanty knowledge of these southern regions. The maps of 1762 have still the south continent prodigally displayed, reach. ing as far as $20^{\circ} \mathrm{S}$. into the Pacific itself; the maps of 1775 show not a trace of it, although, even so late as I773, Kerguelen believed he had seen it in lat. $49^{\circ} \mathrm{S}$. and long. $70^{\circ} \mathrm{E}$. ; what he saw was Kerguelen Island. It was Cook who had the honour of proving that the "Great South Continent" was a mere chimera.

In March 1770 , after the observation of the transit of Venus, he found New Zealand to be an island. On his second voyage he passed to the south of Kerguelen Island in Fcbruary 1773 , though he appears not to have seen it showing there was no hope for theoretical geographers in, this direction. In the previous month, January I7, he passed the South Polar circle in E. long. $39^{\circ} 30^{\prime}$--the first time the feat had been performed by any explorer-sailing as far south as $67^{\circ} 15^{\prime}$. In the (southern) summer of I773-4 Cook explored the ocean from $175^{\circ}$ to $98^{\circ} \mathrm{W}$. long., and bitween $50^{\circ}$ and $7 \mathrm{I}^{\circ} 10^{\prime} \mathrm{S}$. lat., thus clearly proving the non-existence of a great continent to the South Pacific. In December 1774 he sailed from New Zealand to Magellan's Straits, to convince himself that there was no sign of the supposed continent between $55^{\circ}$ and $56^{\circ} \mathrm{S}$. lat. There he re-discovered the island of St. Pierre, seen by Duclos Guyot in 1756 , and a century earlier by La Roche, and named it South Georgia. On his return he discovered the Sandwich group, and narrowly missed the South Orkney and South Shetland Islands. Cook set out on his third great voyage of discovery in January I777, intending to lay down the exact position of Prince Ldward's and Kerguelen Islands, and make observations on the physical geography of the latter; but ere he could accomplish his aim "this greatest of all discoverers of the x 8th century" met his sad death in February 1779.

A comparison of the maps of $I 762$ and 1785 will suffice to show how much was accomplished by Cook. The chief conclusion come to by the great navigator as the result of his extensive explorations was, that outside of the South Polar circle no stretch of land of any extent could be found, and that if any such existed inside the Autarctic zone, for all productive purposes, indeed even for the sustenance and development of organic life, it was useless. The labours of Cook gave thus a negative result ; it remained to future voyagers to prove whether any continent existed within the Polar circle.

In the third period, that from the beginning of the present century, we have to do with expeditions, which, inside or in the close neighbourhood of the South Pulur circle, have sailed through and explored great stretches of ocean, and examined the coasts and islands of the Polar zone. It is the explorers of this period who have contributed so largely to our knowledge of the physical geography of the Antarctic regions.

In October 1808 . Captain Lindsay saw the Bonnet Group, and in February I819 Smith re-discovered Gerritz or Gerrard's Islands, now known as the South Shetlands. We are indebted for much of our knowledge of the regions south of Cape Horn to the zeal of the American whale and seal fishers, Powell, Palmer, Pendelton, Fanning, and others. To these we owe the discovery of Palmer's Land and the South Orkneys. All agree in describing these lands as wholly bound in ice, almost always cnveloped in dense fogs, and showing scarcely a sprig of vegetation. Here and there from out the mass of ice projects a black peak, which, even at a distance, by its showing no trace of the otherwise universal ice, proclaims itself of a volcanic nature. Numberless birds nestle on these islands, on which no quadrupeds have yet been found; and on the warm sides of the volcanic cones nothing is to be found but multitudes of living penguins, who use them as resting-places. In the surrounding sea is a rich vegetable life, on which the seals and fishes appear to thrive.

The re-discovery of the South Shetland Islands gave a new impulse to Antarctic exploration, in behalf of which an active interest now began to show itself in Europe. The Russian Empire took the lead, and in July r819 sent out two ships, the Wostok and the Merny, under the command of Captains Bellinghausen and Lazaren, who distinguished themselves by their pluck and circumspection. They sailed round and defined South Georgia, and Bellinghausen endeavoured, under the meridian of Greenwich, to get as near the Pole as possible. However, after working his way with great difficulty as far south as $69^{\circ} 25^{\prime}\left(\mathrm{I}^{\circ} \mathrm{II} \mathrm{I}^{\prime}\right.$ W.), the impossibility of penetrating farther through the immense masses of ice compelled him to turn northwards. Another attempt under $18^{\circ} \mathrm{E}$. long. was also in vain, and the advanced season compelled the ships to return to Port Jackson. The expedition set out again in November ; and on January 22,1821 , in $92^{\circ} 19^{\prime}$ W. long., reached $69^{\circ} 33^{\prime}$ S. lat., not far from the ne plus ultra of Cook. On the same day, in $68^{\circ} 27^{\prime}$ S. lat., $90^{\circ} 45^{\prime}$ W. long., Bellinghausen saw an island $4,200 \mathrm{ft}$. high, which he named "Peter the Great Island ;" and on the 29th, in $68^{\circ} 43^{\prime} 20^{\prime \prime}$ S. lat., $73^{\circ} 9^{\prime} 36^{\prime \prime} \mathrm{W}$. long., he saw land of great height, which appeared to him to be a cape belonging to a large continent. This he named "Alexander Land." The land was completely locked in ice, and in the sea itself all life appeared to be extinct. At the South Shetlands Bellinghausen fell in with Captain Palmer, who told him of his discovery of Palmer's Land.

The voyages of these Russian explorers, who returned home in the middle of the year $182 \mathrm{r}$, were undoubtedly, as South Polar explorations, the most important which had hitherto been undertaken. They almost circumnavigated the Pole at an average distance of $30^{\circ}$, explored a larger tract inside the Polar circle than ever had been done before, and discovered the first Polar-land. Moreover, they completed a series of valuable hydrographical researches, and it is to be lamented that these are still 
inaccessible to all who are unacquainted with the Russian language.

The next important expedition after the Russian one was that of Captain Weddell, during the years 1822.24, whose observations Dr. Neumayer considers perfectly trustworthy and very valuable, notwithstanding the aspersions of a subsequent explorer, Dumont d'Urville, whose own expedition was resultless. Weddell's labours embrace valuable materials on currents, the variation of the compasses, and nautical and meteorological matters. What is of great interest, is his voyage to a high south latitude in January and February 1823 . With his two little vessels, the 7 ane, of 160 tons, and the Beaufoy, of 65 tons, he made his way from the South Orkneys between great masses of ice, and reached, on the zoth February, in $33^{\circ} 20^{\prime} \mathrm{W}$. long., to $74^{\circ} 15^{\prime} \mathrm{S}$. lat., the highest which had hitherto been attained. He found the sea here so free from ice, that he named it "George IV. Sea," and expressed his belief that it would be an easy matter to approach much nearer to the South Pole. Having convinced himself that no land of any importance existed in this direction, he turned northwards.

In I829 Captain Henry Foster was sent out by the British Government for the purpose of making observations on the physical geozraphy of these regions. $\mathrm{He}$ fixed his quarters at Pendulum Bay, on the island of Deception, whose east end was fixed by Weddell at $63^{\circ} 2^{\prime} \mathrm{S}$. lat, and $60^{\circ} 45^{\prime} \mathrm{W}$. long. Foster stayed here from Jan. ro to March 6, and carried on a series of valuable hydrographical observations. Among other things he determined the length of the simple seconds pendulum. Before his departure he fixed in an exposed position a self-registering maximum and minimum thermometer, which in the year 1842 was found by Captain Smiles, who found the minimum temperature during $\mathrm{I} 3$ years to have been $-205^{\circ}$ Cent. Unfortunately the index of the maximum thermometer had got out of order and could not be read.

Captain Biscoe, with two small ships, the Tula and the Lively, went out in the year I83o. The highest latitude reached by him was $68^{\circ} 5 \mathrm{r}^{\prime} \mathrm{S}$., under $12^{\circ} 22^{\prime}$ E. long. On the 16 th of March, 1831 , he found Enderby's Land, and on February 15, 1832, he discovered Adelaide Island, one of a series which rans in a westerly direction, each of which bears the name of its discoverer. Behind these towers to a considerable height the stretch of land now known as Graham's Land. From the observations of Biscoe and others, we learn that beyond the 6oth parallel of latitude east winds prevail. The results of this expedition were of high importance; but notwithstanding that some maintain Graham's Land and Alexander Land to have no connection, Dr. Neumayer believes this still remains an open question.

The discoveries of Biscoe to the south of the Indian Ocean were to some extent confirmed by Kemp, who, in the end of 1833 , in $60^{\circ} \mathrm{E}$. long. and Jjust inside the Polar circle, discovered the land known by his name. The insular condition of this as well as of Enderby's Land might be held as established, if any dependence could be placed upon the statements of Morrell, an American voyager of 1823 ; in him, however, Dr. Neumayer puts little faith.

The Messrs. Enderby of London, in the year 1838, fitted out two little ships, the Eliza Scott and the cutter
Sabrina, the command of which they gave to Captain Balleny. The scene of Balleny's discoveries was the waters south of New Zealand, a quarter hitherto but little explored. On February 9, 1839 , he discovered three islands, the centre one being in $66^{\circ} 44^{\prime} \mathrm{S}$. lat., and $163^{\circ} \mathrm{I} \mathrm{I}^{\prime}$ E. long. He did not manage to make his way farther south than $69^{\circ}$ in $172^{\circ} 11^{\prime}$.E. long. During the month of February, he sailed westwards on the $65^{\text {th }}$ parallel, and on the 3 rd March, in $118^{\circ} 30^{\prime} \mathrm{E}$. long. and $65^{\circ} 25^{\prime} \mathrm{S}$. lat., he found what is now known as Sabrina Land. More than once previous to this he believed he had seen signs of land, but the dense fogs prevented him from verifying his conjectures. In pursuing these discoveries in lower latitudes, the two little ships suffered much from violent storms, in one of which the Sabrina was lost with all hands.

\section{(To be continued.)}

\section{BELGIAN CONTRIBUTIONS TO ASTRONOMY}

Tableau de l'Astronomie ăans 'hémisphère austral et dans l'Inde.-De l'Astronomie dans l'Académie Royale de Belgique, Rapport séculaire (1772-1872). Par Éł. Mailly. (Bruxelles, F.Hayez, I872.)

TWO publications by the same author lie before us, each meriting a separate notice. Of the first-an extract from the Mémoires de l'Académie Royale de Belgique,-it is difficult to speak more highly in many respects than it deserves. Learned and full as to its matter, clear and perspicuous in style, it tells in a very pleasant as well as instructive manner the story of southerii astroncmy. A good deal of misapprehension, we bcliers, exists as to the beauty of that part of the heavens which is for ever hid from European eyes. The Southern Cross seems to be more remarkable for its associations than its grandeur; and Canopus, the only gem of extraordinary brilliancy which never rises here, is yet outshone by our familiar Dog-star. Some parts indeed of the southern Galaxy are extremely luminous; and this may well b= admitted without subscribing to the assertion of a somewhat flighty Hellenic observer, that around the bow of Sagittarius it gives light enough to read the smallest print! and the marvellous variable $\eta$ Argus, rangins from rivalry with Sirius down to the edge of invisibility without a telescope, is an object of interest for which, in its own way, we might seek a parallel in vain. But on the whole we may well feel that there is nothing in the hidden region to compensate a voyage to gaze upon it. Nor indeed is that region as extensive as, without reflectio: might be supposed. The part of the sky which never rises being equal to that which never sets, its radius is the distance of the pole from the $\mathrm{N}$. horizon; and mare inspection will show that this is no preponderating portion of the whole, if to the visible hemisphere we add all thit part, which, though beneath the horizon at any one time, will successively come into view at other hours of day and night. All this is of course perfertly obvious to any student of astronomy; but we mention it because the idea is perhaps not often realised, how little, comparatively, of the sky we lose in our latitudes, and that little not of the most interesting character.

If, however, we exchange the naked eye for the telescope, 